\title{
Tensile Bond Strength and SEM Analysis of Enamel Etched with Er:YAG Laser and Phosphoric Acid: A Comparative Study In Vitro
}

\author{
Luis H. SASAKI ${ }^{1,2}$ \\ Paulo D. C. $\mathrm{LOBO}^{2}$ \\ Yumi MORIYAMA ${ }^{3}$ \\ Ii-Sei WATANABE ${ }^{4}$ \\ Antonio B. VILLAVERDE ${ }^{2}$ \\ Celso Shin-Ite TANAKA ${ }^{1}$ \\ Eduardo H. MORIYAMA ${ }^{2,3}$ \\ Aldo BRUGNERA Jr. ${ }^{2}$ \\ ${ }^{1}$ Departament of Prosthodontics, Bandeirante University of São Paulo, São Paulo, SP, Brazil \\ ${ }_{2}^{2}$ Institute of Research and Development, University of Vale do Paraíba, São José dos Campos, SP, Brazil \\ ${ }^{3}$ Division of Biophysics and Bioimaging, Ontario Cancer Institute, Toronto, Ontario, Canada \\ ${ }^{4}$ Institute of Biomedical Sciences, University of São Paulo, São Paulo, SP, Brazil
}

\begin{abstract}
Er:YAG laser has been studied as a potential tool for restorative dentistry due to its ability to selectively remove oral hard tissue with minimal or no thermal damage to the surrounding tissues. The purpose of this study was to evaluate in vitro the tensile bond strength (TBS) of an adhesive/composite resin system to human enamel surfaces treated with 37\% phosphoric acid, Er:YAG laser $(\lambda=2.94 \mu \mathrm{m})$ with a total energy of $16 \mathrm{~J}(80 \mathrm{~mJ} /$ pulse, $2 \mathrm{~Hz}, 200$ pulses, $250 \mathrm{~ms}$ pulse width), and Er:YAG laser followed by phosphoric acid etching. Analysis of the treated surfaces was performed by scanning electron microscopy (SEM) to assess morphological differences among the groups. TBS means (in MPa) were as follows: Er:YAG laser + acid (11.7 MPa) > acid (8.2 MPa) > Er:YAG laser $(6.1 \mathrm{MPa})$, with the group treated with laser+acid being significantly from the other groups $(\mathrm{p}=0.0006$ and $\mathrm{p}=0.00019$, respectively). The groups treated with acid alone and laser alone were significantly different from each other $(\mathrm{p}=0.0003)$. The SEM analysis revealed morphological changes that corroborate the TBS results, suggesting that the differences in TBS means among the groups are related to the different etching patterns produced by each type of surface treatment. The findings of this study indicate that the association between Er:YAG laser and phosphoric acid can be used as a valuable resource to increase bond strength to laser-prepared enamel.
\end{abstract}

Key Words: Er:YAG laser, enamel etching, dental composite.

\section{INTRODUCTION}

Enamel etching is an important step during composite restorative procedures. Experimental and clinical evidence suggest that failure in maintaining resin restoration marginal integrity could ultimately lead to: [i] marginal microleakage $(1,2)$, [ii] marginal discoloration (3) and [iii] pulpal inflammatory response $(4,5)$. Therefore, the development of new techniques to increase the bond strength between the dental surface and the adhesive/composite resin systems (e.g. mechanical adhesion) may have profound therapeutic implications in dentistry.

Among the various techniques currently in use to promote dental surface conditioning (6), high-output lasers, such as Er:YAG laser, have been studied as an alternative method to selectively remove oral mineralized tissues for restorative purposes $(7,8)$. Hard dental tissue ablation by Er:YAG laser is based on the absorption of light energy by the water and hydroxyapatite 
present in the enamel, which have high absorption coefficient close to $2.94 \mu \mathrm{m}(8,9)$. This laser has been used for removal of enamel and dentin caries with no evidence of thermally induced damage to the surrounding tissues and/or to the pulp (10). Moreover, when used at appropriate doses, Er:YAG laser can selectively remove hydroxyapatite crystals present on enamel surface resulting in an irregular surface pattern that could potentially improve the micromechanical retention of adhesive systems to the enamel (11-13).

The purpose of this study was to evaluate in vitro the tensile bond strength (TBS) of an adhesive/composite resin system to human enamel surfaces treated with $37 \%$ phosphoric acid, Er:YAG laser $(\lambda=2.94 \mu \mathrm{m})$ or Er:YAG laser followed by phosphoric acid etching. Analysis of the treated surfaces was performed by scanning electron microscopy (SEM) to assess the morphological differences among the groups.

\section{MATERIAL AND METHODS}

\section{Specimen Preparation}

All procedures of this study were previously approved by the institutional Ethics in Research Committee. Eighteen sound extracted human third molars were cleaned with $0.5 \%$ sodium chloride solution, decoronated and the crowns were bisected in a mesiondistal direction with a water-cooled low-speed double-faced diamond disc, providing two halves (buccal and lingual surfaces). A total of 36 enamel specimens were obtained, polished with non-fluoridated pumice and rubber cups for $10 \mathrm{~s}$ and embedded in self-curing acrylic resin, leaving a sufficient testing area.

\section{Enamel Surface Etching and SEM Analysis}

Specimens were randomly assigned to 3 groups $(\mathrm{n}=12)$ and, in each specimen, a $4 \times 4 \mathrm{~mm}$ area was treated. The first group was etched with $37 \%$ phosphoric acid for $30 \mathrm{~s}$, thoroughly rinsed with distilled water for $60 \mathrm{~s}$ and gently air dried. The second group was irradiated with Er:YAG laser $(\lambda=2.94 \mu$ m; Kavo Key, Kavo Corp. Biberach, Germany) using total energy of $16 \mathrm{~J}(80 \mathrm{~mJ} /$ pulse, $2 \mathrm{~Hz}, 200$ pulses total, $250 \mathrm{~ms}$ pulse width). During laser treatment, the pre-determined area was irradiated using a handpiece supplied with the laser system. The third group was treated with laser followed by acid etching using the parameters described above. SEM analysis was performed to compare the morphological changes occurred in the specimens after each treatment protocol. Two specimens per group were sputter-coated with gold to provide a conformal conductive coating and analyzed with a scanning electron microscope (Model LEO $1450 \mathrm{VP}$, LO, Zeiss, Germany) at magnifications of $\times 500, \times 2,000$ and $\times 5,000$.

\section{Thermocycling and Bond Strength Test}

After enamel etching, an adhesive system (Single Bond; 3M/ESPE, St. Paul, MN, USA) was applied twice on the treated area and air-dried for $10 \mathrm{~s}$. Composite buttons (Z250; 3M/ESPE; 4x4 mm, $2.2 \mathrm{~mm}$ ) were placed onto the adhesive-coated surface, adhesive excess was removed with a sharp explorer and lightcuring was performed for $15 \mathrm{~s}$ at each side (60 s total). The 30 remaining specimens $(n=10)$ were submitted to a thermocycling regimen of 700 cycles between $6^{\circ} \mathrm{C}$ and $55^{\circ} \mathrm{C}$ for $24 \mathrm{~h}$ in deionized water. For the TBS test, the specimens were tested in a Universal Testing Machine (MTS 810.23M, Material Test System; Norwood, MA USA) running at a crosshead speed of $0.5 \mathrm{~mm} / \mathrm{min}$. The maximum strength value (immediately before rupture) was recorded in MPa for further comparisons.

\section{Statistical Analysis}

Data were expressed as mean \pm SD. Statistical significance of differences among groups was determined by the paired two-tailed Student's t-test. Differences were considered statistically significant for $\mathrm{p}<0.05$.

\section{RESULTS}

\section{Strength Bond Test}

Figure 1 shows the TBS means of the experimental groups.

The group treated with laser and acid etching $(11.7 \pm 2.2 \mathrm{MPa})$ presented statistically significant higherTBS means than the group irradiated with Er:YAG laser alone $(6.1 \pm 0.8 \mathrm{MPa} ; \mathrm{p}=0.00019)$ or etched with acid alone $(8.2 \pm 0.5 \mathrm{MPa}, \mathrm{p}=0.0006)$. The group treated with Er:YAG laser alone had statistically significant lower TBS means than the acid-etched group $(\mathrm{p}=0.0003)$. 


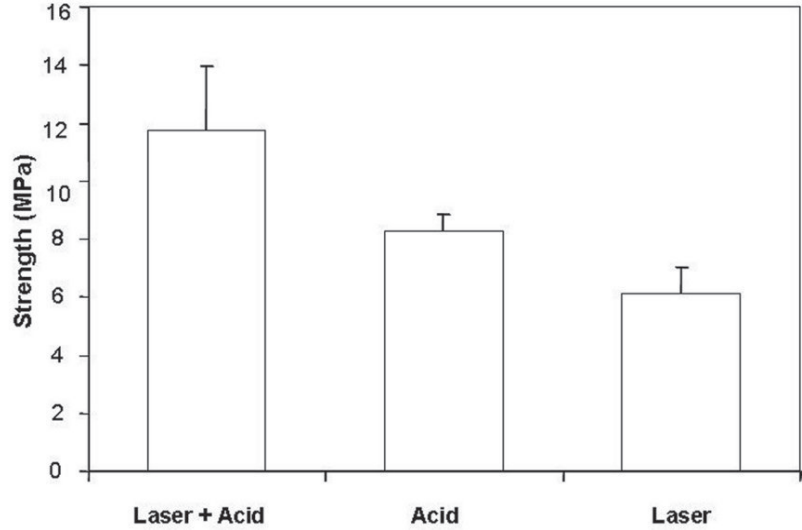

Figure 1. TBS means $( \pm \mathrm{SD})$ for each experimental group.

\section{SEM Analysis}

The structural analysis of enamel surfaces corroborated the results of the TBS testing. The acidetched group showed a more homogeneous etching pattern on the treated surface (Figs. 2 A,B). Specimens conditioned with Er:YAG laser alone showed areas of ablated tissue with non-lased enamel within the irradiated area (Fig. 3 A,B). Figure 4 (A and B) shows that technique using Er:YAG laser irradiation followed by phosphoric acid etching resulted in a more homogeneous surface pattern than that exhibited by the specimens treated with laser alone.
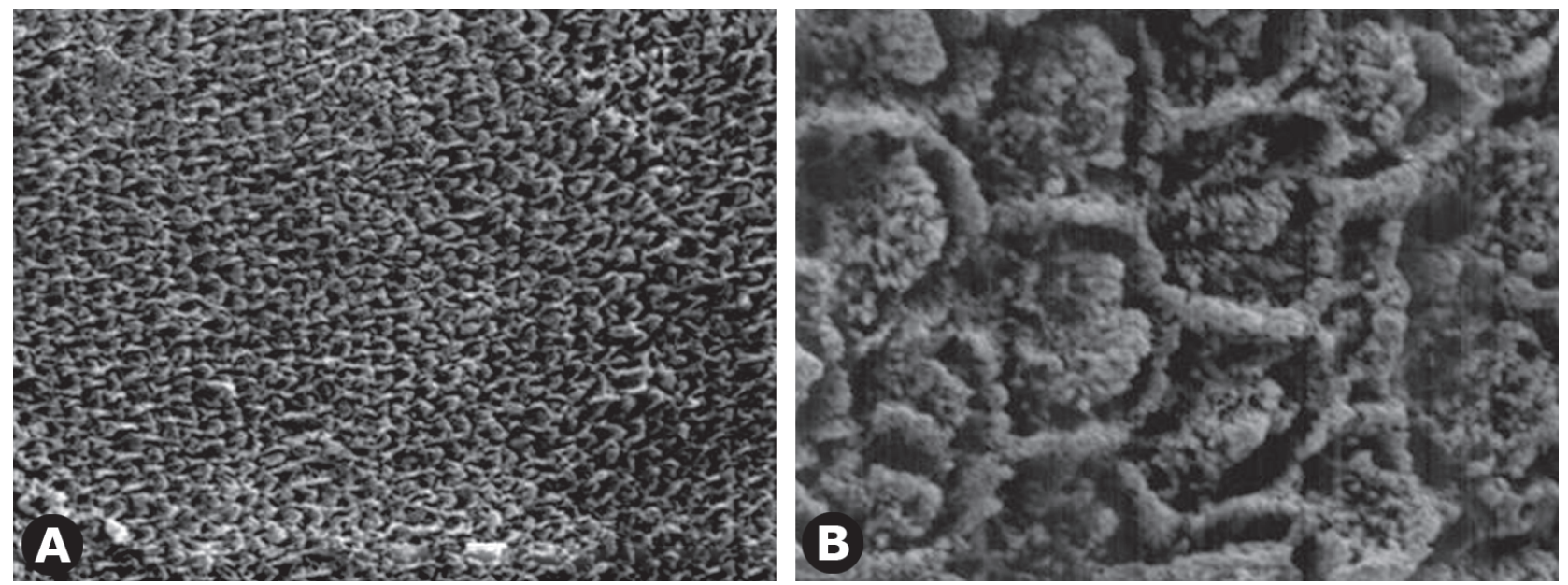

Figure 2. SEM micrographs of enamel surface etched with $37 \%$ phosphoric acid gel for $30 \mathrm{~s}$. Areas with preferential removal of prism core material can be observed and the prism peripheries relatively intact (SEM $\times 500$ - $\mathrm{A}$ and $\times 5000-\mathrm{B}$ ).
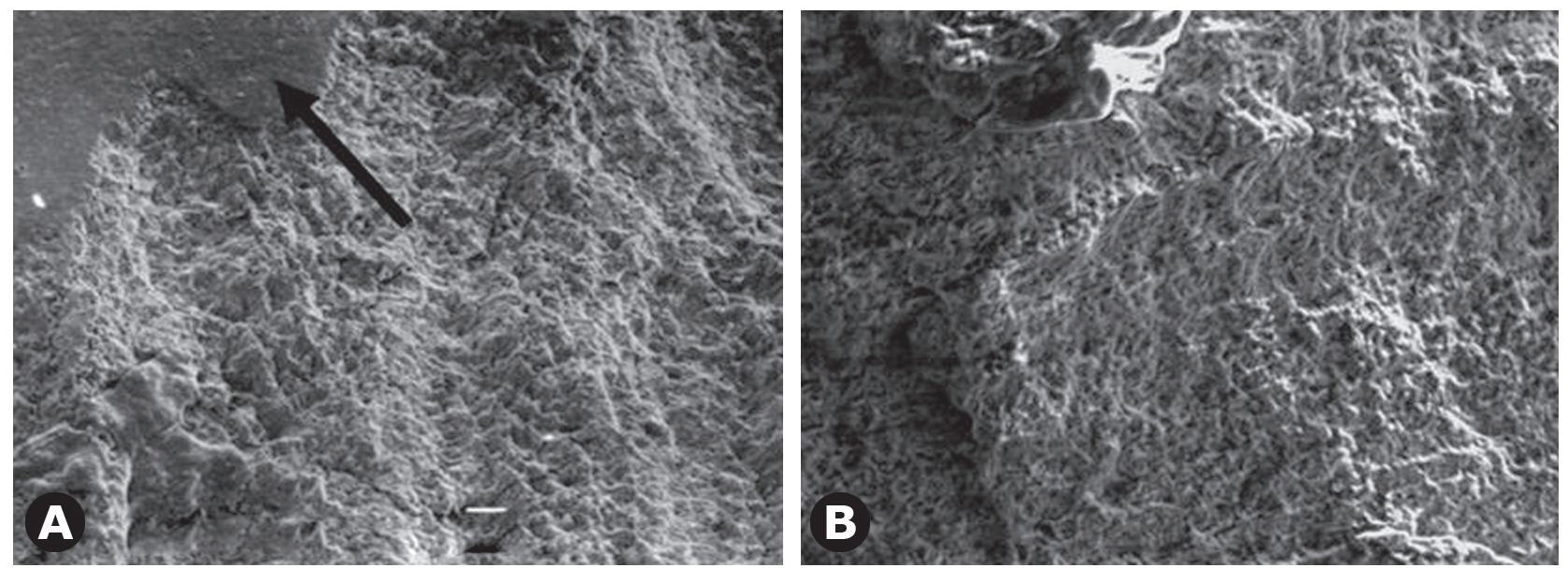

Figure 3. Enamel surface etched with Er:YAG laser. Irregular areas on the surface due to tissue removal and intact area can be observed. $($ SEM $\times 500-A$ and $\times 2000-B)$. The arrow shows untreated enamel surface within the irradiated area. 


\section{DISCUSSION}

Dental oral tissues and water have high absorption peaks in the infrared region close to $2.9 \mu \mathrm{m}(8)$, which coincides with the wavelength of Er:YAG laser, used in the present study. The process by which Er:YAG laser promotes tissue removal is based on the absorption of radiation energy by water molecules present in the dental hard tissues, which is rapidly heated to boiling temperature producing vapor. As a result, the pressure increases within the irradiated area, resulting in local microexplosions and ejection of microparticles of dental hard tissue with minimal or no thermal side effects (14).

Others lasers have also been tested for modifying the surface of dental hard tissues $(15,16)$, however local temperature rise with sever thermal side effects, such as tissue melting and carbonization, were observed. These damages could cross the dentin barrier, resulting in potential damage to the pulp $(17,18)$.

The mechanism of enamel conditioning for composite restorative purposes using either chemical or physical methods is not simply a surface treatment, but rather a selective tissue removal of the external layer of enamel, resulting in microscopic surface irregularities through which the adhesive system should penetrate and provide retention (19). Furthermore, the created surface pattern is strongly dependent on the employed etching technique. Accordingly, in the present study, specimens conditioned with Er:YAG laser followed by phosphoric acid etching showed significantly higher bond strength compared to specimens that were treated with Er:YAG laser alone. Specimens etched exclusively with $37 \%$ of phosphoric acid presented a more homogeneous conditioning pattern of the enamel surface with the presence of honeycomb-like structure, as illustrated in Figures 2A and 2B. This surface pattern produced by conventional phosphoric acid etching is considered as the ideal for adhesive procedures on enamel surface (20).

The lower TBS means observed in the specimens treated with Er:YAG laser alone may be attributed to the non-homogeneous conditioning of enamel surface produced by the laser irradiation, as enamel areas were left untouched by the laser beam (Figs. 3A,B). However, specimens treated with Er:YAG laser followed by phosphoric acid etching presented higher TBS means than those treated exclusively with either acid or Er:YAG laser irradiation. The SEM micrographs presented in Figures $4 \mathrm{~A}$ and $4 \mathrm{~B}$ suggest that the increase of TBS means is due to the fact that the phosphoric acid effectively etched the non-lased spots that remained within the irradiated area.

The observation that the combination of Er:YAG laser and phosphoric acid presented higher bond strength values to composite than the use of phosphoric acid or Er:YAG laser alone, should be subject of further investigation, since it holds the potential to become a suitable method for conditioning enamel surface for composite restoration.
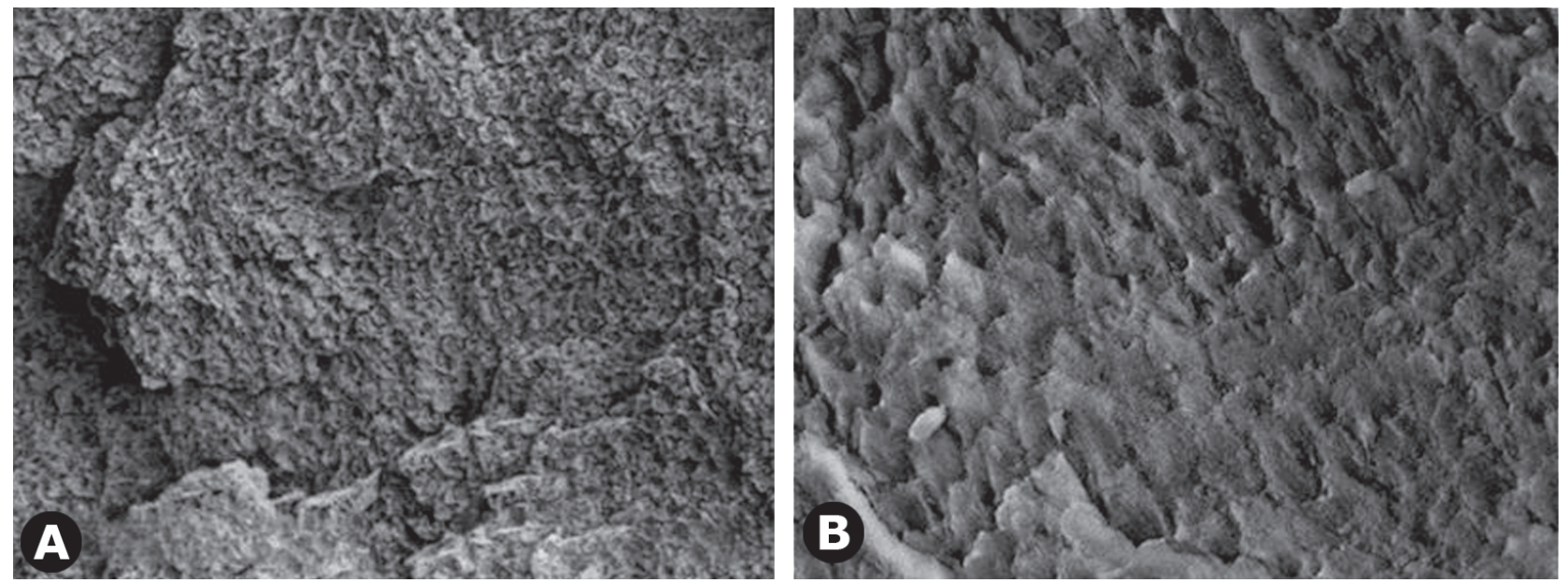

Figure 4. Enamel surface etched with Er:YAG laser and 37\% phosphoric acid for $30 \mathrm{~s}$. The topographical view of the surface is more similar to the etching patterns produced by $37 \%$ phosphoric acid gel treatment $(\mathrm{SEM} \times 500-\mathrm{A}$ and $\times 2000-\mathrm{B})$. 


\section{RESUMO}

A tecnologia a laser tem sido estudada como uma ferramenta potencial para uso em odontologia devido à sua habilidade em remover tecido ósseo com um mínimo ou nenhum dano aos tecidos vizinhos. O objetivo deste estudo é comparar in vitro a resistência à tração do sistema adesivo em esmalte tratado com ácido fosfórico a $37 \%$, laser Er:YAG $(\lambda=2,94 \mu \mathrm{m})$ com energia total de $16 \mathrm{~J}(80 \mathrm{~mJ} / \mathrm{pulso}, 2 \mathrm{~Hz}, 200$ pulsos e largura de pulso de $250 \mathrm{~ms}$ ) e com a combinação laser Er:YAG seguido por ácido fosfórico. $\mathrm{O}$ teste de resistência à tração foi usado para comparar a resistência à tração em cada grupo. Foi também realizada microscopia eletrônica de varredura para permitir a análise das diferenças morfológicas entre os grupos. Foram obtidos os seguintes valores médios de resistência para os grupos tratados com: laser (6,1 MPa), ácido fosfórico (8,2 MPa) e laser mais ácido $(11,7 \mathrm{Mpa})$. Amostras tratadas com laser e ácido apresentaram valores maiores de resistência do que amostras com laser ou ácido isoladamente. A análise da microscopia eletrônica revelou diferenças que corroboram os resultados, demonstrando que diferenças de resistência entre os grupos são devidas às diferenças entre os padrões superficiais resultantes. Nossos resultados sugerem que a combinação do laser Er:YAG com ácido fosfórico pode ser usada como um método para aumentar a resistência à tração do sistema esmalte resina.

\section{ACKNOWLEDGEMENTS}

The authors would like to thank KAVO Ltd, Prof. Francisco Moral and Prof. Durval Rodrigues Junior for the assistance and technical support.

\section{REFERENCES}

1. Santini A, Plasschaert AJ, Mitchell S. Effect of composite resin placement techniques on the microleakage of two selfetching dentin-bonding agents. Am J Dent 2001;14:132-136.

2. Poskus LT, Placido E, Cardoso PE. Influence of adhesive system and placement technique on microleakage of resinbased composite restorations. J Adhes Dent 2004;6:227-232.

3. Bergenholtz G. Evidence for bacterial causation of adverse pulpal responses in resin-based dental restorations. Crit Rev Oral Biol Med 2000;11:467-480.

4. About I, Murray PE, Franquin JC, Remusat M, Smith AJ. Pulpal inflammatory responses following non-carious class $\mathrm{V}$ restorations. Oper Dent 2001;26:336-342.

5. Hayashi M, Wilson NH. Marginal deterioration as a predictor of failure of a posterior composite. Eur J Oral Sci 2003;111:155-162.

6. Van Meerbeek B, Van Landuyt K, De Munck J, Hashimoto M, Peumans M, Lambrechts P, et al.. Technique-sensitivity of contemporary adhesives. Dent Mater J 2005;24:1-13.
7. Kim ME, Deuk-Jin J, Kim KS. Effects of water flow on dental hard tissue ablation using Er:YAG laser. J Clin Laser Med Surg 2003;139-144.

8. Bertrand MF, Brulat N, Lazzarini V, Marcato G, Namur S, Roca JP. Er:YAG laser cavity preparation and semi-direct composite resin restoration: a microleakage study. Photom Laser Surg 2008;26 (in press).

9. Frentzen M, Koort HJ. Histological investigation of mid infrared laser ablation of dental hard tissue. In: International Congress on Laser in Dentistry, 3. Salt Lake City, Aug., 6-8, 1992. Proceedings. Bologna: ISLD. 1992;243-244.

10. Oelgiesser D, Blasbalg J, Ben-Amar A. Cavity preparation by Er-YAG laser on pulpal temperature rise. Am J Dent 2003;16:96-98.

11. Hibst R, Keller U. Experimental studies of the aplication of the Er:YAG laser on dental hard substances: I. Measurement of the ablation rate. Laser Surg. Med 1989;9:338-344.

12. Oudhof HAJ, Breart M, Samy C, De Gee AJ, Van de Kuij P. The comparasion of adhesive dentin bonding with Er:YAG laser and conventional techniques. In: International Congress on Lasers in Dentistry 1996, Jesusalen. Proceedings. Bologna: Monduzzi Editore, 1996. p. 103-105.

13. Hossain M, Nakamura Y, Yamada Y, Kimura Y, Nakamura G, Matsumoto K. Ablation depths and morphological changes in human enamel and dentin after Er:YAG laser irradiation with or without water mist. J Clin Laser Med Surg 1999;17:105109 .

14. de Souza-Gabriel AE, Chinelatti MA, Borsato MC, Pécora JD, Palma-Dibb RG, Corona SA. Effect of ER:YAG laser irradiation distance on superficial dentin morphology. Am J Dent. 2006;19:217-221.

15. Lin CP, Lee BS, Lin FH, Kok SH, Lan WH. Phase, compositional, and morphological changes of human dentin after Nd:YAG laser treatment. J Endod 2001;27:389-393.

16. Moriyama EH, Zangaro RA, Villaverde AB, Lobo PD, Munin E, Watanabe IS, et al.. Dentin evaluation after Nd:YAG laser irradiation using short and long pulses. J Clin Laser Med Surg 2004;22:43-50.

17. Moriyama EH, Zangaro RA, Lobo PD, Villaverde AB, Pacheco MT, Watanabe IS, et al.. Optothermal transfer simulation in laser-irradiated human dentin. J Biomed Opt 2003;8:298-302.

18. Raucci-Neto W, De Castro LM, Corrêa Afonso AM, Da Silva RS, Pécora JD, Palma-Dibb RG. Assessment of thermal alteration during class $\mathrm{V}$ cavity preparation using the Er:YAG laser. Photomed Laser Surg 2007;25:281-286.

19. Wright GZ, McConnell RJ, Keller U. Microleakage of Class V composite restorations prepared conventionally with those prepared with an Er:YAG laser: a pilot study. Pediatr Dent $1993 ; 5: 425-426$

20. Sharpe AN. Influence of the cristal orientation in human enamel on its reactivity to acid as shown by high resolution microradiography. Arch. Oral Biol 1967;12:583-591.

Accepted February 29, 2008 